\title{
Cosmology, Morality and Resource Development: SHP election outcomes and moves to establish a separate Hela Province
}

\section{Nicole Haley}

There have been calls for the establishment of a separate Hela province for the best part of three decades now, and although such a province has not come to fruition the Somare-led national government evidently is sympathetic to the needs and wishes of the Hela peoples. In May 2003, for instance, The National reported that the current government had promised the people of the Southern Highlands a separate Hela province by 2007 (The National 11 May 2003). More recently it has come to light that the national government, through the Boundaries Commission, will 'look into the possibility of a separate province for Hela in 2005' (The National 13 August 2004). This paper will comment on the push for the establishment of a Hela province and on the supplementary election results in the Southern Highlands Province (SHP). It is argued that in recent years the support for a Hela province has waned in many parts of the province and that formation of a Hela province may well exacerbate emergent ethnic conflicts.

\section{Calls for a Hela province}

Newspaper articles and letters to the editor since independence reveal that the Huli have long dreamed of a separate Huli province. Initially, the calls for a separate province simply focussed on the fact that SHP is a large province with a large population, and that, as such, it warranted being split into two or three separate provinces (Post-Courier 18 April 1978). However, within a very short time the calls for a separate province became synonymous with calls for a separate Huli province.

The early proponents of this movement argued that the formation of a separate Huli province would promote stability and the preservation of Huli culture (Post-Courier 3 May 1978). On 18 May 1978, the Post-Courier reported that local government councils in Koroba, Kopiago, Tari, Komo and Magarima were demonstrating to push for the formation of a separate province 'to be called the Hela Province'. These demonstrations were followed by formal local government council resolutions rejecting the introduction of provincial government (Post-Courier 3 August 1978), ${ }_{1}^{1}$ and coincided with public announcements that local government councils in the west of the province were 'not ready for 
provincial government in the Southern Highlands Province' (Post-Courier 30 August 1978). Proponents of the Hela province officially opposed provincial government for the Southern Highlands, arguing that the Tari, Magarima, Koroba, Komo and Lake Kopiago districts lacked economic and educational development - which they did. ${ }^{2}$ They sought a separate province and argued that provincial government should be postponed until such time as they had gained the 'necessary educational qualifications and experience' required to successfully run a provincial government (Post-Courier 30 August 1978).

Although the movement was not officially endorsed by the Southern Highlands Area Authority, the arguments employed tended to echo those which the Authority had itself employed when opposing self-government and independence several years earlier (see Haley and May, this volume). Individual members of the Authority were certainly sympathetic to the push. Andrew Andaija, the then president of the Southern Highlands Area Authority and later premier of SHP, for instance, was reported as saying that many of the movement's complaints were genuine (Post-Courier 18 May 1978). He did not, however, wish to see the province 'break into pieces', pushing instead for service provision.

By the mid 1980s the push for a Hela province had gained momentum, due in part to the ongoing neglect of the west. This same neglect "served as an essential basis for the development of [a Huli/Hela] social and political identity" (Ballard J.A. 1989:142). In 1986, Andrew Wabiria, the former member for Koroba-Lake Kopiago, presented the prime minister with a petition calling for the recognition of the Hela people across provincial boundaries. The petition was from the recently formed Hela Gimbu Association. It demanded a share of oil royalties, insisted that all labour for development projects be recruited in the Hela area, and called on the national government to provide goods and services 'or face serious trouble'. Specifically, the petition demanded a road between Tari and the Gulf Province, improved telecommunications, an upgrade of the Tari airstrip, and fully funded health and education services throughout the Hela region (National Times 12 April 1986).

In more recent times, Huli people have called on the national government to split the Southern Highlands in two, because of the continuous armed hold-ups on the Nipa road, frequent roadblocks at Poroma, Magarima and Nipa, and ongoing ethnic conflict between the peoples of the west and the east, which has meant that the peoples in the west of the province have been cut off from Mendi, their provincial headquarters (PNG Gossip Newsletter 6 September 2000). Several of the key candidates in the 2002-2003 national elections took up the call for a Hela province. James Marape, runner-up in the Tari-Pori open electorate, for instance, held a press conference in August 2002 in which he demanded a more equitable distribution of services within the province, noting that if the Hela people continued to be denied essential services then SHP would go the way of 
Bougainville (Independent 28 August 2002). He and others, including Damien Arabagali, the current chairman of the Hela Gimbu Association, have continued the call for a separate Hela province.

\section{Cosmology and the idea of a Hela province}

The peoples occupying the western end of SHP, namely the Duna, Huli, and Bogaia, along with their Paiela neighbours, share the view that they descend from a common ancestor, known as Hela (Haley 2002b). Accordingly, they often refer to each other as brothers (Glasse 1965:33; Biersack 1995:14-16), considering themselves sons of the same father. On the basis of this connection there have been calls for many years for the formation of a Hela province, which would take in the resource-rich districts occupied by the Duna, Huli and Paiela, namely the Komo-Margarima, Tari-Pori, Koroba-Lake Kopiago, Nipa-Kutubu and Porgera-Lagaip districts (Vail 1995:360; Haley 2002b). ${ }^{3}$ The project is for the most part Huli owned and driven, and lacks wider support, although it does have the support of many key political figures. What local-level support it has derives directly from discontent over the lack of services in the western end of the province and the lack of benefits accruing from present resource developments. It is this same discontent which led to the formation of the United Resources Party by Anderson Agiru.

These peoples also hold that the world is bound up in a process of loss, degradation and decline. This is expressed in the way they engage with their environment and in the ways they perceive and interpret environmental and social changes. Ethnographers of the Duna and Huli have repeatedly commented on this all-pervading theme (Frankel 1986; Goldman 1983; Ballard C. 1995; Strathern 1991; Stürzenhofecker 1993; Haley 2002b), which is common to the region more generally (see also Jorgensen 1981, 1985; Poole 1986; Biersack 1991, 1995). Myths found amongst these groups reveal a common belief that the world originally consisted of formless clay-like mud which was given shape and strengthened by ancestral spirits; that the cardinal elements of the universe were born of an original ancestress; and that the landscape as fashioned by the ancestors is held securely in place by a subterranean cane or cane-like python known as the 'root of the earth'. These myths also reveal that the way of the world is such that the fertile substance, which sustains the universe, by nature dissipates, and that the expenditure of this substance will bring about the world's end.

The peoples living in the western end of SHP similarly share the belief that they are part of a regional system deeply rooted in mythology and ritual, and that the fertility of their region is morally constituted. This means they must act and behave in certain ways for their world to be fertile. Such was the basis of their pre-colonial cosmologies. Indeed, in the past, Duna, Huli, Hewa, Bogaia and Paiela participated collaboratively in ground-seeding and ground-making 
rituals which sought to ensure the ongoing fertility of the region (Haley 2002b). These rituals, which involved the sacrifice of human substances and body parts in order to replenish the root of the earth, were enacted along ritual 'roads' which criss-crossed the region.

Specifically, there were at least five major ritual roads crossing the Duna region, these being Kirau atia, Ambua atia, Hewari atia, Nona atia and Miliano atia, and another, Ukuam Sama, traversing the Bogaia region. One thing these roads had in common is that they all terminated outside the Duna area. The most southerly road, Kirau atia, started in Bogaia country near Bulago and proceeded via Nogoli to Gelogili in Huli country (Gelote in the Huli literature. See Goldman 1979; Ballard C. 1995). Ambua atia started on the Oksapmin side of the Strickland Gorge and, it seems, originally terminated at Bebenite, south of Tari. ${ }^{4}$ The third road, Hewari atia, commenced at the Duna parish of Angora in the mid Pori River area and travelled through the Logaiyu and Urei river valleys into the Ipili-speaking areas and thence to Mt Kare where it terminated. Nona atia commenced in the Strickland Gorge on Yokona ground, traversed the south Hewa area, and likewise terminates at Mt Kare. The final road, Miliano atia, commenced in Hewa country, traversed Duna country from north to south, and terminated in the Bogaia area. Ritual sites linked by these roads typically featured ground oil seeps and natural gas seeps, which became the focus of the rituals which sought to replenish fertile substance in order to restore and ensure the ongoing fertility of the region.

Even today, despite the almost complete absence of indigenous ritual practice, Duna hold to the belief that moral behaviour conserves fertile substance, and that immoral behaviour sees it depleted and will ultimately bring about the world's end. Ongoing fertility continues to be something Duna must negotiate through appropriate moral behaviour and proper social intercourse (Haley 2002b). Indeed it is their actions which render specific substances, particularly (but not exclusively) fluid substances, either inimical to growth or capable of inducing fertility. Linked to this is the notion that inappropriate moral behaviour can render a previously fertile substance infertile (see also Ballard C. 2000:210). Mineral resources are seen as examples of fertile substance which originate from deep within the root of the earth. As such they must be properly handled and engaged with in a morally appropriate manner. Duna hold that social intercourse in relation to mineral extraction must also be properly managed, and that the flow of resources elsewhere must be curtailed, lest the fertile substance sustaining the world be depleted at a rate which brings about the end of the world.

How is this relevant to a discussion of politics? For generations, Duna, Huli and Paiela and their more immediate neighbours performed cooperative rituals aimed at re-making and re-fashioning the ground so as to ensure the ongoing fertility of the entire region. Specifically, these involved replenishing the earth's 
fertile core. In the contemporary context, Duna claim the Huli and Paiela have forgotten this. They cite their exclusion from Mt Kare as a case in point. Indeed although many Duna clans in the upper Pori area directly descend from Ko-Yundikia (the spirit associated with Mt Kare) and several old men from these groups had sacrificed pork to Ko-Yundikia in their own lifetimes, Duna were chased away from Mt Kare during the height of the gold rush. Duna feel that their Huli and Paiela 'brothers' should have recognised and acknowledged their claims, especially as they had been cooperatively responsible for Ko-Yundikia's ritual propitiation for generations. Furthermore, Duna maintain that they continued observances at Mt Kare well into the early 1970s, long after the Huli had abandoned these practices. ${ }^{5}$

Duna, today, charge the Huli, in particular, with having forsaken both the regional ritual projects which they once strongly promoted (Ballard C. 1994; 2000:213) and the ties which made such cooperative performances possible. Instead of being concerned to preserve the fertile substance of the earth's core, Duna see the Huli and Ipili as pillaging it. They regard the gold, oil and gas being extracted at Porgera, Mt Kare, Nogoli, Moran, Kutubu and Gobe as examples of this fertile substance, and insist that the Huli are wantonly consuming fertile substance which should be conserved so as to sustain them and the world.

This blood taken along Kirau atia and Ambua atia was fertiliser for gardens, medicine for pigs and children. Those things started here. But where they stored them, that was at Nogoli [Hides Gas], on the Huli side. They have forgotten the true origins of Kirau atia and Ambua atia. We believe that there is something important here - mineral oil, gas or something. We don't know. Our ancestors told us not to dig the ground in the [Strickland] Gorge. They said, if we did, this thing would come out and burn us all ... Where those roads ended they are extracting gas. We too are responsible for that gas. Those things started here. (Andrew Makano 1997; Robinson Fieldnotes Notebook 4:129-130).

In the contemporary context, Duna feel that Huli have sold them out. They charge the Huli with monopolising for themselves the fruits born of their cooperative ritual efforts.

The boy went that way and the girl went this way. She went with a female pig. That pig didn't take a walk by itself. The people here took it up that way. They would call the name of each group. One group would bring it and give it to the next, all the way to Gelogili ... Before we [Huli and Duna] stayed together like a married couple. Our union bore fruit. Our union bore the oil and gas ... Those things are as much ours. But they [the Huli] are using it, expending it. They have forgotten us (Sane Noma 1994; Haley Fieldnotes Notebook 3:48; 54). 
The Duna likewise charge the Huli with having forgotten that they are brothers who trace descent from a common ancestor, Hela. Almost without exception, Duna now preface conversations and statements about mining and other large-scale development projects with statements to the effect that the Duna, Ipili and Huli are brothers - Hela ingini — sons of the same father. Such appeals to common descent also form the basis of an anti-Huli sentiment which now permeates all aspects of Duna discourse.

Despite espousing the rhetoric of Duna, Huli and Paiela as brothers, Duna have not embraced the growing calls for a Hela province (Biersack 1995; Vail 1995; Goldman n.d.). They vehemently oppose such a project, seeing it as a Huli owned and driven project which will bring them no benefits (cf. Goldman n.d.:12). Some even view the calls for the formation of a Hela province as sinister in intent, fearing that if the province comes to pass they will lose both their land and their identity (Haley 2002b).

The Southern Highlands is big. The Hela people are there. Duna people are underneath ... Hela had Duna, Huli and Obena. True we are brothers. But we Dunas don't fight. If there is trouble we sit down and talk. We don't fight. Hulis fight first. They think only of vengeance. We are different to Hulis. We come underneath Hela, not underneath the Huli. About this talk of a Hela province - we don't support this kind of talk. If the Huli want a province, let them have their own province. We don't want to be part of it. Give us our own province - a Duna province. Don't cover us up with this talk of Hela. That is something belonging to the Huli - they are misusing the name of Hela. The leaders here, we don't support that, we want to promote our customs and our culture. We don't want photocopied customs being sprayed all over the place. We are Duna, and we must not diverge from this (Jospeh Henepia 2004; Haley Fieldnotes Notebook 40:21).

\section{The 2002-2003 elections ${ }^{6}$}

In the face of such concerns, the past decade has seen growing calls for Duna unity. Campaigning in the Lake Kopiago sub-district (that part of the Koroba-Lake Kopiago electorate which is ethnically Duna) in the lead-up to the 1997 and 2002 national elections focused on the urgent need for Duna political unity to secure national representation (Haley 2002a, 2002b, 2004). Both elections were promoted locally as the 'final election', the last chance to gain political representation before the world's end (Robinson 2002). In 1997, for instance, several of the candidates formulated a Memorandum of Agreement for Duna Unity (Haley 2002a), which in part read:

D. All Parties realise that there has got to be only one person representing the Duna, Hewa and Bogaye people in Parliament. 
E. All parties realise that for the last 23 years the people of Duna, Hewa and Bogaye have being used, manipulated and marginalised for the benefits of a few elite [Huli] from the Koroba area (Memorandum of Agreement For Duna Unity, June 1997).

The role played by cultural identity and ethnicity in campaigning during both the 1997 and 2002/2003 national elections was profound. Dance festivals and dance competitions, in which much energy was spent on articulating Duna identity, were held on a regular basis, and sponsored by the various Duna candidates. Men and women, young and old, participated in earnest, with all participants being encouraged to dress in 'pure' Duna fashion.

In the Koroba-Lake Kopiago electorate the past two elections have produced electoral contests based very much on ethnicity, and have been concerned with who, from a Duna perspective at least, might provide for and best facilitate the advancement and unity of the Duna people, since the Duna hold the Huli directly responsible for their disadvantage and lack of services. Indeed, when Duna complain about a lack of support from successive national governments, their complaints are invariably directed towards the Huli, for they see themselves as having been colonised and governed by the Huli, and charge the Huli with monopolising access to the state.

Duna today fear that they are at risk of losing their cultural identity, especially in the face of Huli calls for a Hela province. They feel they are under the control of the Huli, and seek to represent themselves politically, to preserve the sociality and morality upon which their collaborative ritual endeavours were predicated, to reclaim control over ancestral lands transformed by mining (cf. Jacka 2001), and to (re-)make and (re-)fashion the world for the benefit of future generations.

That Duna fears and desires dramatically influenced the outcome of the supplementary elections held in 2003 might be illustrated by some observations on the elections. The failed 2002 national election saw 19 men contest the Koroba-Lake Kopiago open electorate. Of these candidates 6 were Duna and 13 were Huli. By contrast the 2003 supplementary elections were contested by 10 Huli candidates and only 2 Duna candidates. This came about because four of the Duna candidates stood aside in favour of Petrus Thomas, a first-time campaigner. They publicly stated that they stood aside for the sake of Duna unity. Thomas, a well known Mendi Muruk and one-time Kumul (national) rugby league player, campaigned without money on the platform that Duna people were suffering. He promised not to play politics but instead to unite the Duna and improve their situation. Duna people were generally of the view that he did not support a Hela province. Such a project, they knew, would not improve their lot. The other Duna candidate, Ben Peri, endorsed by the United Resources Party, actively supported the Hela movement, as did several of the Huli candidates. 
The Huli have a clear demographic advantage in the Koroba-Lake Kopiago open electorate. In 2002 it was home to some 43,500 Huli, Duna, Hewa and Bogaia speakers. $^{7}$ Of these, 24,850 (57 per cent) were Huli speakers, 16,055 (37 per cent) were Duna speakers, 2,310 (5.3 per cent) were Hewa speakers and 285 (0.7 per cent) were Bogaia speakers. In the light of this, the results are quite remarkable. First, the two Duna candidates between them picked up two thirds (66 per cent) of the votes cast, despite the fact that Duna make up only 37 per cent of the electorate.

An examination of the ballot box counts reveals that Thomas and Peri both picked up large numbers of Huli votes. In Peri's case this had much to do, I believe, with the fact that he was endorsed by the disgraced former SHP governor, Anderson Agiru, ${ }^{8}$ and because he has backed the Hela province movement with its calls for a greater share of SHP's resource wealth. Thomas, however, picked up the votes of disgruntled and what I would call marginalised Hulis - perhaps what Goldman (this volume) has termed 'naturalised Hulis', people who are now choosing to emphasise their Duna connections over their Huli ones. Indeed Thomas picked up many votes in the bilingual census units, which strongly suggests that there is not as much support for the Hela province as its promulgators would have us believe. ${ }^{9}$ Further evidence for this is the fact that the 2003 results saw Hami Yawari (from Kutubu) elected as governor, against the trend which has seen the regional seat held by a representative of one of the three big ethnic groups.

Whilst it is clear that the Huli continue to seek a separate province, it should not be assumed that all the Hela peoples support this movement; in fact they do not. For more than a decade now the Duna have been calling for a 'pure' Duna province and have been seeking to differentiate themselves from their Huli neighbours. Duna do not want to be part of a Hela province, and are angered when Huli spokesmen presume to speak on their behalf.

There are 19 Council wards within Kopiago Basin and another 13 council wards within the Auwi/Logaiyu area ... These are all Duna census divisions. All of us within these census divisions are innocent. We are not supporting this Hela province. The people pushing for a Hela province are using our name, the Duna name, without our permission. They don't speak for us. The Hela name belongs to all of us, not just the Huli. They have appropriated it and now we are getting the blame. Our name, the Duna name is being spoiled and we too are being blamed when trouble comes up on the Tari side (David Lundape 2004; Haley Fieldnotes Notebook 40:33).

If it is indeed the Somare government's intention to split the Southern Highlands, then serious consideration should be given to the formation of a Huli province as opposed to a Hela province, for the formation of a Hela province 
may well exacerbate the emergent ethnic conflicts, which have been brewing for decades. Alternately, consideration should be given to the formation of electorates which map more closely the ethnic divisions within the province; this would ensure a political voice for groups such as the Duna who currently number more than 30,000. Such discussion may, however, be purely academic as in 2002-2003 the Huli went from holding four seats in the National Parliament to holding only two, and this may well mean that there is now far less likelihood of progress towards a Hela province during the 2002-2007 parliament.

Whatever the case, there is no doubt that the Huli will continue to press for services in their areas and will continue to push for their own province. Back in 1978, the late Andrew Andaija called for calm, urging people that what they needed was services and not necessarily a province of their own. If Papua New Guinea's leaders were to provide the basic services Andaija fought for, then much of the discontent in the western end of the province would be quelled and the ethnic conflicts which are brewing might also be averted. The creation of a Hela province will not solve the Southern Highlands' woes, rather it will merely serve to fuel ethnic conflicts of a different kind.

\section{References}

Ballard, C. 1994 'The centre cannot hold: trade networks and sacred geography in the Papua New Guinea highlands', Archaeology in Oceania 29(3):130148.

-1995 ‘The Death of a Great Land: Ritual, History and Subsistence Revolution in the Southern Highlands of Papua New Guinea'. Unpublished Ph.D. thesis, The Australian National University.

-2000 'The fire next time: the conversion of the Huli apocalypse', Ethnohistory 47(1):205-225.

Ballard, J. A. 1983 'Shaping a political arena: The elections in the Southern Highlands'. In D. Hegarty (ed.), Electoral Politics in Papua New Guinea: Studies on the 1977 National Elections. Port Moresby: University of Papua New Guinea, pp.174-195.

1989 'Polarisation of a Province: The 1982 Election in the Southern Highlands'. In P. King (ed.), Pangu returns to power: the 1982 elections in Papua New Guinea. Canberra: Australian National University, Department of Political and Social Change. Political and Social Change Monograph No. 9, pp139-162.

Biersack, A. 1991 'Prisoners in time: millenarian praxis in a Melanesian valley', in A. Biersack (ed.), Clio in Oceania: Toward a Historical Anthropology. Washington: Smithsonian Institution Press, pp. 231-296. 
1995 'Introduction: the Huli, Duna and Ipili peoples yesterday and today', in A. Biersack (ed.), Papuan Borderlands: Huli, Duna, and Ipili Perspectives on the Papua New Guinea Highlands. Ann Arbor: University of Michigan Press, pp. 1-54.

Frankel, S. 1986 The Huli Response to Illness. Cambridge: Cambridge University Press.

Glasse, R. M. 1965 'The Huli of the Southern Highlands', in P. Lawrence and M.J. Meggitt (eds), Gods Ghosts and Men in Melanesia: Some Religions of Australian New Guinea and the New Hebrides. Melbourne: Oxford University Press, pp. 27-49.

Goldman, L. R. 1979 'Kelote: an important Huli ritual ground', Oral History $7(4): 14-18$.

_ 1983 Talk Never Dies: The Language of Huli Disputes. London: Tavistock Publications.

-n.d. 'Decorated being in Huli - parleying with paint'. Unpublished paper.

Haley, N. C. 2002a 'Election fraud on a grand scale: the case of the KorobaKopiago open electorate', in R. J. May and R. Anere (eds), Maintaining Democracy: The 1997 Elections in Papua New Guinea. Port Moresby: University of Papua New Guinea Press in conjunction with State, Society and Governance in Melanesia project, The Australian National University, pp. 123-139.

_2002b 'Ipakana Yakaiya: Mapping Landscapes, Mapping Lives — Contemporary Land Politics Among the Duna'. Unpublished PhD thesis, The Australian National University.

2004 'A failed election: the case of the Koroba-Lake Kopiago Open Electorate', in P. Gibbs, N. Haley and A. McLeod (eds), Politicking and Voting in the Highlands: The 2002 Papua New Guinea National Elections. State, Society and Governance in Melanesia Discussion Paper 2004/1. Canberra: State, Society and Governance in Melanesia Project, Research School of Pacific and Asian Studies, The Australian National University, pp. 1626.

Jacka, J. 2001 'Coca-Cola and kolo: land, ancestors and development', Anthropology Today 17(4):3-8.

Jorgensen, D. 1981 'Taro and Arrows: Order Entropy and Religion among the Telefolmin'. Unpublished PhD thesis, University of British Columbia.

- 1985 'Femsep's last garden: a Telefol response to mortality, in. D.E.A. Counts and D. Counts (eds), Aging and Its Transformations: Moving Toward Death in Pacific Societies. New York: University Press of America, pp. 207-26. 
1990 'Placing the past and moving the present: myth and contemporary history in Telefolmon', Culture 10(2):47-56.

1997 'Who and what is a landowner? Mythology and marking the ground in a PNG mining project', Anthropological Forum 7(4):599-628.

Poole, F. J. P. 1986 'The erosion of a sacred landscape: European exploration and cultural ecology among the Bimin-Kuskusmin of Papua New Guinea', in M. Tobias (ed.), Mountain People. Norman: University of Oklahoma Press, pp.169-182.

Robinson, R. P. 2002 'The final election', in R.J. May and Ray Anere (eds), Maintaining Democracy: The 1997 Elections in Papua New Guinea. Port Moresby: University of Papua New Guinea Press in conjunction with State, Society and Governance in Melanesia project, The Australian National University, pp.141-148.

Strathern, A. J. 1991 "'Company" in Kopiago', in A. Pawley (ed.), Man And a Half: Essays in Pacific Anthropology and Ethnobiology in Honour of Ralph Bulmer. Auckland: Polynesian Society, pp. 612-615.

Stürzenhofecker, G. 1993 ‘Times Enmeshed: Gender, Space, and History Among the Duna'. Unpublished PhD thesis, University of Pittsburgh.

Vail, J. 1995 'All that glitters: the Mt. Kare gold rush and its aftermath', in A. Biersack (ed.), Papuan Borderlands: Huli, Duna, and Ipili Perspectives on the New Guinea Highlands. Ann Arbor: University of Michigan Press, pp. 343-374.

\section{ENDNOTES}

1 In August 1978 the Koroba local government council for instance resolved that their area lacked economic and education development and that 'Provincial government should only come after people in the west and Magarima area had equal development with the rest of Papua New Guinea (Post-Courier 3 August 1978).

2 The Tari-Magarima road was not opened until mid-1977. Prior to this the western end of the province was effectively isolated (see J.A. Ballard 1983). As a result it was the last part of the province to obtain services and remains to this day the least developed.

3 The movement is reminiscent of the failed 1980s push by the 'Min' (Mountain Ok) peoples to establish a Min province (Jorgensen 1990; 1997:603), which would have incorporated those peoples who trace descent from Afek.

4 According to Chris Ballard (pers. comm. 2001) Bebenite was for a long time the most important Huli gebeanda (ritual site). Some Duna accounts, especially those collected at the Kopiago end, suggest that Ambua atia terminated at Gelogili (Gelote). Whilst this may have been the case following Bebenite's demise as a ritual centre, my informants in the upper Pori Valley were also clear that this route went to Bebenite and indeed on to Ambua Mountain.

5 Chris Ballard (2000:216) notes that conversion amongst the Huli was 'a speedy and wholesale occurrence' and that 'most rituals ... ceased to be publicly or openly performed during the 1960s'. Conversion to Christianity took place amongst the Huli earlier than it did amongst the Duna. While Christian missionaries entered the Huli area in 1951, they did not enter the Duna area until 1964. It is therefore plausible, as Duna claim, that they were maintaining sites such as Ko-Yundikia kini into the 1970s. Their claims are certainly consistent with those of other ritual specialists who had maintained remote sites elsewhere in the region. 
6 In 2002, elections in six of nine Southern Highlands electorates were declared null and void. Supplementary elections for these six seats were held successfully in April/May 2003.

7 This figure and those that follow have been calculated from the 1990 census figures and the 1980-1990 population growth rate of 1.9 per cent per annum. They bear little resemblance to the most recent PNG census figures or the number of people listed on the Common Roll, which are both grossly inflated (see Haley 2002a).

8 Agiru remains extremely popular in the western end of the province - as evidenced by the fact that Jacob Sekewa, endorsed by Agiru for the provincial seat, ran second to Hami Yawari, despite the fact he was a first time contestant and relatively unknown in the province.

9 It is interesting to note that a recent letter to the editor, signed 'Hela elite, Tari, SHP' asserts that 'Thomas does not represent the bulk of the people of Hela' (The National 8 September 2004). 